\title{
[WHEN I SAY BACKDOOR I MEAN THE WAY A LOT]
}

When I say backdoor, I mean the way a lot

of young hitters begin, afraid and ready to bolt, a wooden bat beaten up. The room, the sun, the sky, the moon put up last. The barn, the beach, the metalworks, the shed. When we say lazy eye, it means if only it had ever wanted to see.

Consider the eardrum, rolled like a fiddlehead fern, inserted into another's ear like a tractor with a metallic tip, extended into another discipline, a phantom brain, Laura dolls with their eyes popped out. Fifteen incalculable years calculated: a new diving facility.

Forty-four facial muscles in humans; the dead serve the living; they know we're nothing special.

Your giant food's no good here, honey.

Your liver is connected only to you. Your head stares directly.

You know of reeds that have waited, collecting themselves for years.

And there's the husband, anyone's guess.

You say, runners go but do not mean it much.

It is a better way to get what we need, to find space.

When I say backdoor, I mean the world, I mean come freely and of someone else's volition. I mean it meanly and with no teeth. I mean it until I no longer can mean it. 